\title{
TolC is Required for Pathogenicity of Xylella fastidiosa in Vitis vinifera Grapevines
}

\author{
Joseph D. Reddy, ${ }^{1}$ Stephanie L. Reddy, ${ }^{1}$ Don L. Hopkins, ${ }^{2}$ and Dean W. Gabriel ${ }^{1}$ \\ ${ }^{1}$ Department of Plant Pathology, University of Florida, Gainesville 32601, U.S.A.; ${ }^{2}$ Mid-Florida Research and Education Center, \\ University of Florida, Apopka 32703, U.S.A.
}

Submitted 28 July 2006. Accepted 27 October 2006.

\begin{abstract}
Xylella fastidiosa infects a wide range of hosts and causes serious diseases on some of them. The complete genomic sequences of both a citrus variegated chlorosis (CVC) and a Pierce's disease (PD) strain revealed two type I protein secretion plus two multidrug resistance efflux systems, and all evidently were dependent on a single tolC homolog. Marker exchange mutagenesis of the single tolC gene in PD strain Temecula resulted in a total loss of pathogenicity on grape. Importantly, the $t_{o l C^{-}}$mutant strains were not recovered after inoculation into grape xylem, strongly indicating that multidrug efflux is critical to survival of this fastidious pathogen. Both survival and pathogenicity were restored by complementation using tolC cloned in shuttle vector pBBR1MCS-5, which was shown to replicate autonomously, without selection, for 60 days in Temecula growing in planta. These results also demonstrate the ability to complement mutations in $X$. fastidiosa.
\end{abstract}

Additional keywords: leaf scorch

Plants produce a diverse array of anti-microbial compounds, including phytoanticipins, which are pre-formed, and phytoalexins, which are synthesized in response to pathogen attack (Dixon 2001; Grayer and Harborne 1994; Hammerschmidt 1999; Harborne 1999; Osbourne 1996). The importance of these compounds in general plant defense has been demonstrated by the increased susceptibility of mutants impaired in production of phytoanticipins or phytoalexins (Frey et al. 1997; Glazebrook and Ausbel 1994; Papadopoulou et al. 1999). In addition, several studies have demonstrated that plant antimicrobial compounds can be present in locally sufficient concentrations to inhibit both fungal and bacterial growth (Del Sorbo et al. 2000; McNally et al. 2003; Pierce et al. 1996; Schoonbek et al. 2001). Successful pathogens are thought to circumvent the toxic effects of these antimicrobial compounds by enzymatic inactivation or by blocking toxic compound uptake (vanEtten et al. 2001). More recently, multidrug efflux has been suggested as a third important mechanism for bypassing plant defenses in Erwinia chrysanthemi (Barabote et al. 2003), E. amylovora (Burse et al. 2004), and some members of the family Rhizobiaceae, including Agrobacterium tumefaciens (Palumbo et al. 1998; Peng and Nester 2001), Rhizobium etli (Gaonzales-Pasyo and Martinez-Romero 2000), and Bradyrhozobium japonicum (Krummenacher and Narberhaus 2000).

Although much research has been devoted to the multidrug efflux pumps of bacterial pathogens of animals, the emphasis

Corresponding author: D. W. Gabriel; Telephone: +1.352.392.7877; Fax: +1.352.392.6532; E-mail: gabriel@ biotech.ufl.edu has been on the role these pumps play in the development of bacterial resistance to antibiotics, rather than on resistance to innate host defenses (Sheldon 2005). Other than the recent suggestive studies in Erwinia spp. and the family Rhizobiaceae, a general role for multidrug efflux in bacterial plant pathogenesis in order to circumvent innate defenses has not been demonstrated.

In gram-negative bacteria, multidrug resistance (MDR) efflux pumps are composed of three protein components, two of which are localized in the inner membrane and one, TolC, that traverses both the periplasm and outer membrane (Koronakis et al. 2004; Nikaido 1996; Paulsen 2003; Zgurskaya and Nikaido 2000). The process of MDR efflux is energy dependant and utilizes either ATP or the transmembrane electrochemical gradient. At least five characterized families of MDR efflux pumps exist in bacteria: the ATP-binding cassette (ABC) family (Davidson and Chen 2004), the major facilitator (MF) family (Pao et al. 1998; Saier et al. 1999), the small multidrug resistance (SMR) family (Paulsen et al. 1997), the resistance-nodulation-cell division (RND) family (Tseng et al. 1999), and the multidrug and toxic compound extrusion (MATE) family (Brown et al. 1999). All utilize TolC as a common periplasm/outer membrane protein component (Fralick 1996; Lomovskaya and Lewis 1992; Ma et al. 1993).

In addition to (defensive) MDR efflux, TolC also is essential for type I-dependent secretion of a variety of degradative enzymes and offensive effectors, some of which are antibiotic and others involved in plant or animal pathogenicity. These include a variety of hydrolases (proteases, phosphatases, esterases, nucleases, and glucanases) and protein toxins, including hemolysins and bacteriocins (Delepelaire 2004; Hwang et al. 1997; Koronakis et al. 2004; Wandersman and Delepelaire 1990). Orthologs of tolC are highly conserved among diverse gram-negative pathogenic bacteria, and strains typically carry multiple homologues per strain (Sharff et al. 2001), including all sequenced strains of Xanthomonas, Pseudomonas, and Ralstonia.

Xylella fastidiosa is a gram-negative, fastidious, insect-vectored, xylem-limited bacterium that causes a variety of diseases, some severe, on a wide range of economically important crops, including grape, citrus, coffee, plum, peach, oleander, elm, sycamore, oak, and maple (De Lima et al. 1998; Hartung et al. 1994; Hopkins 1989; Purcell 1997; Wells et al. 1987). The complete genome sequences of a citrus strain that causes citrus variegated chlorosis (CVC) disease (Simpson et al. 2000) and a grape strain that causes Pierce's disease (PD) (Van Sluys et al. 2003) have been determined. No type III secretion system, commonly found in bacterial plant pathogens (Alfano and Collmer 1997), was found in either genome. However, multiple hemolysins and type I system components were present in 
both genomes. More importantly, only a single TolC family homolog was found in each genome, indicating that a mutational approach might be productive in investigating a potential role of type I secretion in pathogenesis.
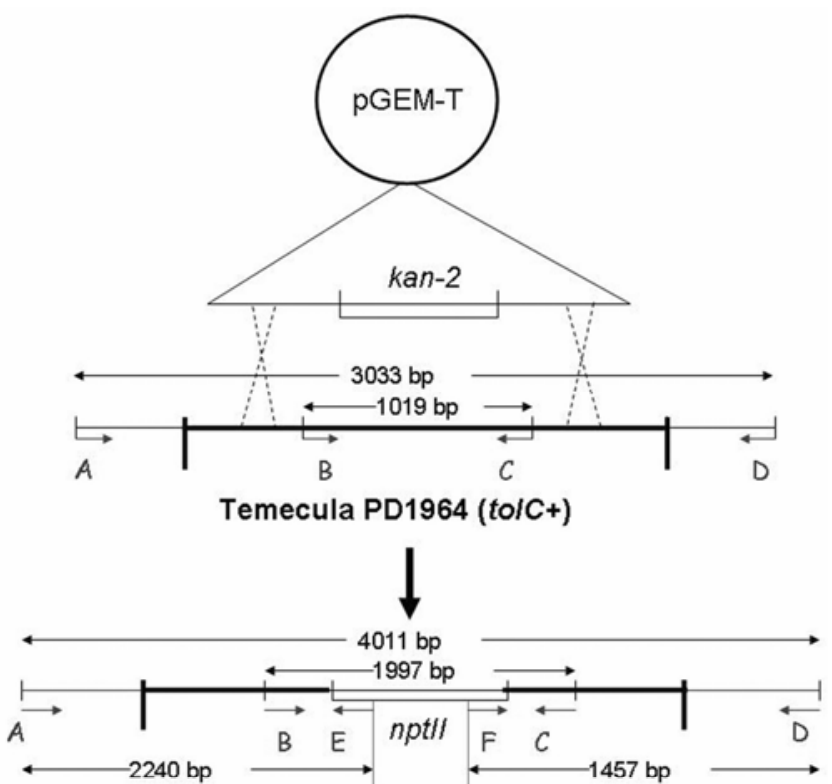

M1 (tolC::kan-2)

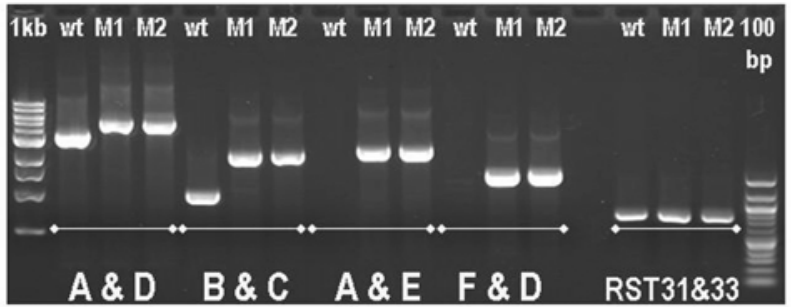

Fig. 1. Marker exchange mutagenesis of tolC using pJR6.3. Polymerase chain reaction $(\mathrm{PCR})$ primers used for insert verification are labeled $\mathrm{A}$ to F. Primer A, 5'-GGCGAACTTGGAATCCTATG; B, 5'-AAGGGCAAGTT CAGGCAC; C, 5'-GACTTCCAGGCCGACTTG; D, 5'-GTCAGTGTTGT GTGTGGATG; E, 5'-ATGCTTGATGGTCGGAAGAG; and F, 5'-GATTC AGTCGTCACTCATGG. Primers RST31 and RST33 are Xylella specific (Minsavage et al. 1994). PCR analysis of marker exchange mutants generated using kan-2 inserted into BamHI site of tolC (PD1964), cloned by PCR into pGEM-T from PD strain Temecula. M1 and M2 are two independent mutants of Temecula following electroporation.
Research on the molecular mechanism of pathogenicity of $X$. fastidiosa has been limited by the fastidious nature of the bacterium, its slow growth, and the lack of any vector suitable for complementation. Several vectors have been constructed or tested for maintenance in X. fastidiosa (da Silva Neto et al. 2002; Guilhabert and Kirkpatrick 2003; Guilhabert et al. 2006; Qin and Hartung 2001; Vanamala and Gabriel 2006), but none have been used successfully for complementation. The purpose of this study was to determine the role of type I secretion in $X$. fastidiosa strain Temecula in causing PD by knockout mutation and complementation of the single tolC homolog in the Temecula genome.

\section{RESULTS}

Generation of $\mathrm{tolC}^{-}$mutants of $X$. fastidiosa Temecula.

Following electroporation of suicide vector pJR6.3 (tolC::kan-2) into Temecula (Table 1), kanamycin-resistant colonies were recovered on PD3 medium at a rate of approximately 50 transformants per microgram of pJR6.3 DNA (Fig. 1). Transformants were colony purified by repeated streaking and two transformants were evaluated for marker exchange interruption at the tolC locus by polymerase chain reaction (PCR) analysis (Fig. 1). The results clearly demonstrated that the tolC gene was interrupted by kan-2, and without evidence of a wildtype tolC copy remaining in both transformants M1 and M2. One of these, M1, was evaluated further and confirmed to be marker exchanged at the tolC locus by Southern blot (Fig. 2).

\section{Pathogenicity and complementation assays of tolC mutant M1.}

Pathogenic symptoms of leaf scorch began to appear 1 month after inoculation of Temecula on grape cv. Carignane; PD symptoms caused by this strain were fully evident by 6 weeks (Fig. 3A). Carignane plants inoculated with the mutant strain M1 at the same time exhibited no symptoms of PD (Fig. $3 \mathrm{~B})$. However, when tolC was reintroduced into M1 using pJR22.2 in trans, pathogenicity was restored (Fig. 3C). This result was confirmed in at least four independent experiments.

\section{In planta growth and survival}

of the $X$. fastidiosa Temecula tolC mutant M1.

Although both Temecula and the complemented tolC mutant strain M1/pJR22.2 were recovered readily from inoculated grape plants 60 days after inoculation, not even a few colonies of $X$. fastidiosa were recovered from plants inoculated with the

Table 1. Bacterial strains and plasmids used

\begin{tabular}{|c|c|c|}
\hline Strains and plasmids & Relevant genotype or description ${ }^{a}$ & Source or reference $^{b}$ \\
\hline \multicolumn{3}{|l|}{ Strains } \\
\hline \multicolumn{3}{|l|}{ Xylella fastidiosa } \\
\hline Temecula & Wild type & Guilhabert et al. 2001 \\
\hline M1 & Temecula marker-exchanged derivative (tolC::kan-2) & This study \\
\hline $\mathrm{M} 1 / \mathrm{pJR} 22.2$ & M1 transconjugant carrying pJR22.2 $\left(\right.$ tolC $\left.^{+}\right)$ & This study \\
\hline \multicolumn{3}{|l|}{ Escherichia coli } \\
\hline DH5 $\alpha$ MCR & F-, 80dlacZM15, endA1, recA1, hsdR17 $\left({r_{\mathrm{k}}}^{-}, m_{\mathrm{k}}{ }^{+}\right)$, supE44, thi-1, gyrA96, relA1, (lacZYA-argF)U169- & Invitrogen \\
\hline \multicolumn{3}{|c|}{ 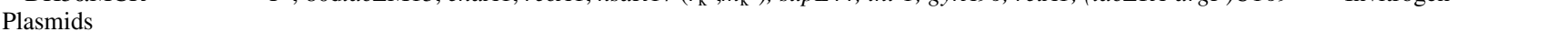 } \\
\hline pBBR1MCS-5 & Rep Bordetella, lacZ, $\mathrm{Gm}^{\mathrm{r}}$ & Kovach et al. 1995 \\
\hline pGEM-T & $\mathrm{Ap}^{\mathrm{r}}, \mathrm{pUC}$ ori, lacZ & Promega Corp. \\
\hline pBlueScript & $\mathrm{Ap}^{\mathrm{r}}$, colE1 ori, lac Z & Stratagene \\
\hline pKLN18 & $\mathrm{Ap}^{\mathrm{r}}, \mathrm{Kn}^{\mathrm{r}}, \mathrm{pUC}$ ori, lac $\mathrm{Z}$ & Newman et al. 2003 \\
\hline pJR6.1 & pGEM-T with pGEM-T with $1,454-\mathrm{bp}$ PCR product from Temecula with tolC $^{+}, \mathrm{Ap}^{\mathrm{r}}$ & This study \\
\hline pJR6.2 & pBlueScript with 972-bp Xma I/BamHI fragment from pKLN18 with $\mathrm{kan}^{-2^{+}}, \mathrm{Ap}^{\mathrm{r}}, \mathrm{Kn}^{\mathrm{r}}$ & This study \\
\hline pJR6.3 & tolC::kan-2 derivative of pJR6.1, $\mathrm{Ap}^{\mathrm{r}}, \mathrm{Kn}^{\mathrm{r}}$ & This study \\
\hline pJR22.2 & pBBR1MCS-5 + 1,458-bp EcoRI/SpeI from pJR6.1, tolC+ & This study \\
\hline pUFJ05 & pBBR1MCS-5 + 978-bp kan-2 fragment from pKLN18 & This study \\
\hline
\end{tabular}

${ }^{\mathrm{a}} \mathrm{Gm}^{\mathrm{r}}, \mathrm{Ap}^{\mathrm{r}}$, and $\mathrm{Kn}^{\mathrm{r}}=$ gentamycin, ampicillin, and kanamycin resistant, respectively; PCR = polymerase chain reaction.

b Sources: Invitrogen Life Technologies, Carlsbad, CA, U.S.A., Promega Corporation, Madison, WI, U.S.A., and Stratagene Inc., La Jolla, CA, U.S.A. 
tolC mutant strain M1, despite at least eight attempts, using both the stem-grinding method and sap-expression method. Because M1 was nonpathogenic on grape, and because we were unable to reisolate M1 from inoculated plants, we compared the growth of the Temecula, M1, and M1/pJR22.2 in planta. Both Temecula and M1/pJR22.2, but not M1, were reisolated readily from the artificially inoculated stems at 0,2 , 24,48 , and $72 \mathrm{~h}$ after inoculation and at similar concentrations.

\section{Sensitivity of M1 to phytochemicals, Silwet L-77,} grape sap, and crude plant homogenate.

Not even a few colonies of M1 were recovered from inoculated plant tissue even a few minutes after inoculation; therefore, the relative resistance of M1 compared with the wild-type Temecula strain to various phytochemicals, the detergent Silwet L-77, grape sap, and crude plant extract was investigated. M1 was found to be highly sensitive to the phytochemicals berberine and rhein and also to the wetting agent Silwet L-77 (Table 2), indicating that multidrug efflux is critical to survival of $X$. fastidiosa. Surprisingly, in four independent experiments,

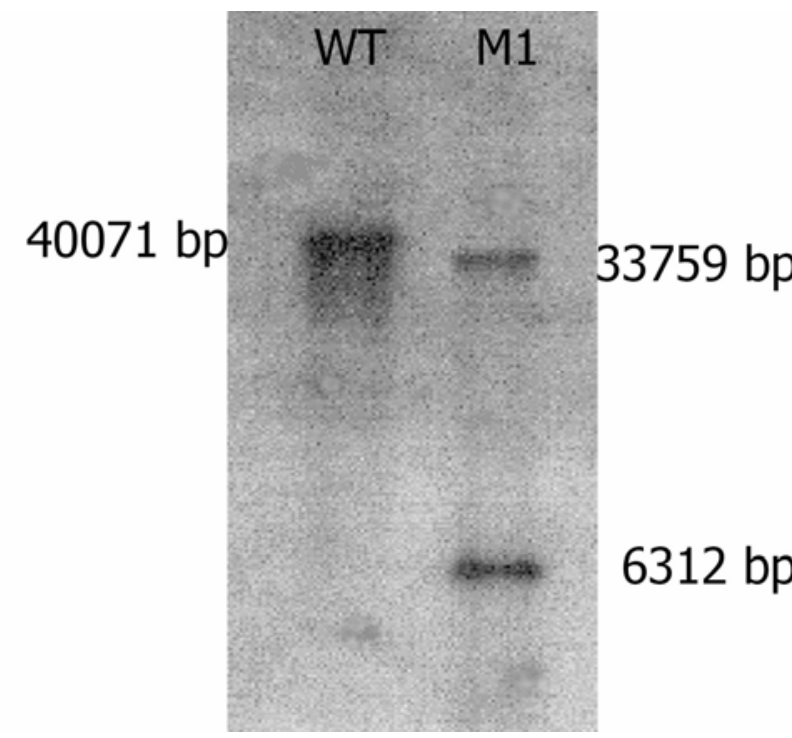

Fig. 2. Southern blot of Xylella fastidiosa DNA wild-type strain Temecula and $t_{o l C^{-}}$mutant derivative M1, digested with $\mathrm{XhoI}$, which is internal to the kan-2 gene. The membrane was probed with ${ }^{32} \mathrm{P}$-labeled tolC DNA (PD1964;1,454 bp) exposure to $90 \%$ grape sap collected in the spring had no detected detrimental effect on the survival of $\mathrm{M} 1$, even after incubation for up to $24 \mathrm{~h}$ (data not shown). However, crude plant homogenate $(\mathrm{CPH})$ from grape was toxic to Temecula and highly toxic to M1 (Table 3). Mutant M1 was sensitive to 9\% CPH after a 60-min exposure and only a few cells recovered after a 1-min exposure to $45 \% \mathrm{CPH}$. Even the wild-type Temecula was $100 \%$ killed after $10 \mathrm{~min}$ of exposure to $90 \%$ $\mathrm{CPH}$, although most cells survived a 1-min exposure time.

\section{In planta stability of pUFJ05}

in the absence of selection for tolC.

Of the 20 Temecula/pUFJ05 colonies randomly isolated 60 days postinoculation from grape xylem sap, 8 were resistant to kanamycin and positive for the presence of pUFJ05 by PCR analysis for the kanamycin gene. The remaining 12 colonies were sensitive to kanamycin and lacked pUFJ05. Plasmid

Table 2. Minimum inhibitory concentrations (MICs) of four phytochemicals and Silwet L77 on Temecula and tolC ${ }^{-}$mutant M1

\begin{tabular}{lccc}
\hline & \multicolumn{2}{c}{ MIC $(\mu \mathrm{g} / \mathbf{m l})$} & \\
\cline { 2 - 3 } Chemical & Temecula & M1 $(\Delta t \boldsymbol{t o l C})$ & Fold difference \\
\hline Berberine & 25 & 0.02 & $1,000 \times$ \\
Genistein & 5 & 0.5 & $10 \times$ \\
Resveratrol & 12.5 & 12.5 & $1 \times$ \\
Rhein & 50 & 0.05 & $1,000 \times$ \\
Silwet L77 & $>2,000 \mathrm{ppm}$ & 20 & $>100 \times$ \\
\hline
\end{tabular}

Table 3. Effect of crude plant homogenates $(\mathrm{CPH})$ from grape on Xylella fastidiosa wild-type strain Temecula and tol $^{-}$mutant-derivative $\mathrm{M}^{\mathrm{a}}$

\begin{tabular}{|c|c|c|c|}
\hline \multirow[b]{2}{*}{ Strain } & \multicolumn{3}{|c|}{ CFU/ml } \\
\hline & $1 \mathrm{~min}$ & $10 \mathrm{~min}$ & $60 \mathrm{~min}$ \\
\hline \multicolumn{4}{|l|}{ M1 (tolC) } \\
\hline SCP buffer & $8 \times 10^{8}$ & $7.5 \times 10^{8}$ & $4.5 \times 10^{8}$ \\
\hline $9 \% \mathrm{CPH}$ & $2.6 \times 10^{8}$ & $4.3 \times 10^{8}$ & $1.1 \times 10^{7}$ \\
\hline $45 \% \mathrm{CPH}$ & 40 & 40 & 0 \\
\hline $90 \% \mathrm{CPH}$ & 0 & 0 & 0 \\
\hline \multicolumn{4}{|l|}{ Temecula } \\
\hline SCP buffer & $2 \times 10^{8}$ & $1.6 \times 10^{8}$ & $2 \times 10^{8}$ \\
\hline $9 \% \mathrm{CPH}$ & $1.7 \times 10^{8}$ & $2.5 \times 10^{8}$ & $3 \times 10^{8}$ \\
\hline $45 \% \mathrm{CPH}$ & $1.7 \times 10^{8}$ & $3 \times 10^{8}$ & $1.5 \times 10^{7}$ \\
\hline $90 \% \mathrm{CPH}$ & $6 \times 10^{7}$ & 0 & 0 \\
\hline
\end{tabular}

a Cells were exposed to SCP buffer and to 90,45 , and $9 \% \mathrm{CPH}$ in SCP for the indicated time periods. Colony counts were made 6 days after plating.



Fig. 3. Grape leaves detached above the inoculation point on the stem of grape plants inoculated with A, Temecula; B, tolC mutant M1; and C, M1/pJR22.2. Photos taken 60 days postinoculation. 
DNA was isolated from two of the positive colonies and cut with restriction endonucleases, and pUFJ05 was observed on an agarose gel stained with ethidium bromide (not shown). The plasmid exhibited bands of expected size, demonstrating autonomous replication of pUFJ05 for 60 days in Temecula growing in planta and without selection.

\section{DISCUSSION}

In this study, tolC knockout mutations were readily obtained by marker-exchange mutagenesis (requiring a double crossover) in strain Temecula, despite repeated failure to obtain knockout mutations of the same gene in the same strain using marker interruption involving a single crossover event and suicide vector integration (Castaneda et al. 2005). This experience is consistent with the observations made by Feil and associates (2003). The reason for failure of marker interruption is still speculative but may involve intolerance of the colEl origin of replication integrated in the $X$. fastidiosa genome (Feil et al. 2003).

Several attempts have been made in a number of labs to generate or identify autonomously replicating vectors that are stable enough to be used for complementation of mutants or for gene function analyses in $X$. fastidiosa. Until now, such a vector had not been identified and it has been difficult or impossible with this species to prove that a mutant phenotype was actually caused by a known physical mutation, because complementation analysis of gene knockout mutants could not be easily performed. The results reported here demonstrate the ability to complement mutations in $X$. fastidiosa using an autonomously replicating vector. Although plasmid stability was not examined carefully in the present study, the autonomously replicating vector $\mathrm{pBBR} 1 \mathrm{MCS}-5$, carrying a replication origin from Bordetella spp., was stable enough in X. fastidiosa to be used for complementation of a mutation affecting pathogenicity. Roughly half of the wild-type strain Temecula colonies reisolated after 60 days of growth without selection in grape xylem retained the plasmid. When pJR22.2 (pBBR1MCS-5 carrying tolC) was used for complementation of strain M1, a tolC knockout derivative of Temecula, $100 \%$ of the reisolated colonies carried the plasmid when assayed 60 and 90 days after inoculation, in three separate experiments. Therefore, tolC appeared to provide a strong selective advantage to $X$. fastidiosa in grape.

In this study, tolC was shown to be both functional and necessary for pathogenicity and, probably, in planta survival of $X$. fastidiosa in grape plants. M1 was completely nonpathogenic to grape and pathogenicity was restored by the addition of the wild-type tolC gene on pJR22.2. M1 never was recovered from inoculated grape plants despite repeated efforts; therefore, it seems likely that tolC is essential to survival of $X$. fastidiosa in grape xylem. Three lines of evidence support this idea. First, tolC provided such a strong selective advantage to M1 that stability of pBBR1MCS-5 was raised from 50 to $100 \%$ after 60 days of growth in planta. Second, M1 was much more sensitive to the antimicrobial compounds berberine (an alkaloid DNA intercalating agent) (Schmeller et al. 1997), genestein (an isoflavone phytoalexin precursor) (Yu et al. 2000), and rhein (an anthraquinone) (Hatano et al. 1999), and also to the surfactant Silwet L-77, than the wild-type Temecula strain, demonstrating that tolC is needed for MDR efflux by $X$. fastidiosa. Finally, M1 was much more sensitive to crude grape plant homogenates than Temecula.

Perhaps surprisingly, exposure to grape sap from uninfected, healthy plants for up to $24 \mathrm{~h}$ had no apparent deleterious effects on M1. However, it is possible that the survival of M1 in the sap used in these experiments was due to the lack of induc- tion of one or more phytoalexins in the healthy grape plants, and that use of grape sap from PD-infected plants would have had a deleterious effect on M1. This hypothesis could be tested and, if true, M1 might be used to identify the phytoalexin. New plant antimicrobial compounds can be discovered by use of MDR efflux inhibitors or by use of bacterial strains, such as M1, that lack an effective MDR efflux system (Tegos et al. 2002). Interestingly, the well-characterized antifungal grape phytoalexin resveratrol $\left(3,5,4^{\prime}\right.$-trihydroxystilbene) (Jeandet et al. 2002) did not affect M1.

It also is possible that M1 survived exposure to grape sap in these experiments because "bleeding" sap was used. Xylem sap varies significantly in $\mathrm{pH}, \mathrm{C}$, and $\mathrm{N}$ composition, particularly during the bleeding stage (Andersen and Brodbeck 1989; Campbell and Strother 1996), when starch and nitrogen reserves in roots are strongly mobilized to support vegetative and reproductive growth (Zapata et al. 2003). Presumably, there also is significant seasonal variation in the composition of antibacterial compounds, including preformed phytoanticipins in grape sap, that may require MDR efflux for survival.

It any case, it seems likely that M1 would have survived or even have grown for a short period of time after artificial inoculation into the xylem of healthy grape plants, only to die upon exposure to the crude plant homogenates during the cellcounting assays. During the tissue-grinding assay, the cells were mixed with the crude homogenate for a period of exposure of approximately $1 \mathrm{~min}$. This exposure time was found to be sufficient to kill $100 \%$ of M1, but only moderately affected Temecula (Table 3). It is not likely that M1 grew for long periods of time in the xylem without causing disease, because M1 was not detected 60 days after inoculation by directly squeezing the sap of inoculated plants onto agar medium. Even avirulent (but presumably $t o l C^{+}$) PD strains are readily detected by this method (Hopkins 1985). In a study of a tolC mutant of $E$. crysanthemii, Barabote and associates (2003) reported a slight increase in population of the tolC mutant during the first $6 \mathrm{~h}$ after inoculation in Witloof chicory, followed by a $60 \%$ reduction in bacterial counts over a 72-h period. Quantitative growth assays of M1 using the sap-squeezing method were not attempted in this study because of the experimental variation that seemed inherent in the method.

We hypothesize that type I secretion in $X$. fastidiosa is needed for more than just defensive survival in a host by MDR efflux - that it also has a pleiotropic offensive role in eliciting disease. In several animal-pathogenic bacteria, type I secretion is implicated in secretion of pathogenicity effectors, including hemolysin and enterotoxin in Escherichia coli, hemolysin in Salmonellai enterica, and cytotoxin in Vibrio cholera (Delepeirae 2004; Li and Nikaido 2004). In addition, type I secretion is implicated in eliciting the resistance response of rice to Xanthomonas oryzae pv. oryzae (da Silva et al. 2004). Analysis of the both the CVC strain 9a5c and PD strain Temecula genomes showed that there are no type III but multiple type I secretion systems, all depending on TolC. Among the earliest symptoms caused by Xylella fastidiosa on grape is a characteristic leaf scorch that, although similar to symptoms of water stress (Goodwin et al. 1988), often occurs in bands, which is suggestive of toxin activity. We currently are testing this hypothesis.

Analysis of the published genomes of both $X$. fastidiosa strains revealed the presence of $\alpha$-hemolysin-like toxins and multiple genes encoding type I effectors of the repeats in toxin (RTX) family (Lally et al. 1999). Effectors found were a bacteriocin (XF2407 in CVC and ortholog PD1427 in Temecula) that resembles a Rhizobium host range factor (Oresnik et al. 1999), hemolysins (XF0175, XF0984, and XF1280 in CVC and orthologs PD0413, PD0282, and PD0536, respectively, in 
Temecula), calcium-binding hemolysin-type proteins (XF0668, XF1011, and XF2759 in CVC and orthologs PD1506, PD0305, and PD2094, respectively, plus an additional calcium-binding protein PD2097), and colicin V precursors (XF0262 and XF0263 in CVC and orthologs PD0215 and PD0216 in Temecula). The presence of such a large group of RTX toxins may be significant because both genomes carry representatives of both major RTX toxin types: the $\alpha$-hemolysin group, whose members are toxic to a very wide range of cell types from many eukaryotic species; and the colicin group, which represents a group with a much more limited eukaryotic host range specificity (Lally et al. 1999).

Regardless of the outcome of these speculations, the absolute requirement for MDR efflux in PD means that development of chemical substances or genetic methods that could block TolC or another component of the efflux system should aid in the control of this economically important disease of grape. The demonstration of the importance of MDR efflux in $X$. fastidiosa extends earlier work in Erwinia spp. and the Rhizobiaceae and may indicate a generally essential role for MDR in bacterial plant pathogenesis.

\section{MATERIALS AND METHODS}

\section{Bacterial strains, plasmids, pathogenicity assays, and general methods.}

All plasmids, $X$. fastidiosa strains, and $E$. coli strains used are listed in Table 1. X. fastidiosa cells were grown in PD3 medium: tryptone $\left(4 \mathrm{~g} \mathrm{liter}^{-1}\right)$, soytone peptone $\left(2 \mathrm{~g} \mathrm{liter}^{-1}\right)$, trisodium citrate $\left(1 \mathrm{~g} \mathrm{liter}^{-1}\right)$, disodium succinate $\left(1 \mathrm{~g} \mathrm{liter}^{-1}\right)$, $\mathrm{MgSO}_{4} \cdot 7 \mathrm{H}_{2} \mathrm{O}\left(1 \mathrm{~g} \mathrm{liter}^{-1}\right), \mathrm{K}_{2} \mathrm{HPO}_{4}\left(1.5 \mathrm{~g} \mathrm{liter}^{-1}\right), \mathrm{KH}_{2} \mathrm{PO}_{4}(1 \mathrm{~g}$ liter $\left.^{-1}\right)$, and $0.1 \%$ (wt/vol) hemin chloride $\left(10 \mathrm{ml} \mathrm{liter}^{-1}\right) ; \mathrm{pH}$ then was adjusted to 7.0 , and soluble potato starch $\left(2 \mathrm{~g} \mathrm{liter}^{-1}\right)$ and agar $\left(15 \mathrm{~g} \mathrm{liter}^{-1}\right)$ were added and autoclaved for $20 \mathrm{~min}$ (Davis et al. 1980). For pathogenicity assays, grape (Vitis vinifera) cv. Carignane plants were inoculated by needle puncture as described (Hopkins 1984). In brief, 10- $\mu$ l droplets of bacterial suspension in SCP buffer (trisodium citrate, $1 \mathrm{~g} \mathrm{liter}^{-1}$; disodium succinate, $1 \mathrm{~g} \operatorname{liter}^{-1} ; \mathrm{MgSO}_{4} \cdot 7 \mathrm{H}_{2} \mathrm{O}, 1 \mathrm{~g}$ liter $^{-1}$; $\mathrm{K}_{2} \mathrm{HPO}_{4}, 1.5 \mathrm{~g} \mathrm{liter}^{-1}$; and $\mathrm{KH}_{4} \mathrm{PO}_{4}, 1 \mathrm{~g} \mathrm{liter}^{-1}$; $\mathrm{pH}$ 7.0; absorbance at optical density of $600 \mathrm{~nm}\left[\mathrm{OD}_{600}\right]=0.25$ ) were placed in the center of three different internodes of each plant, starting with the third or fourth internodes, and a sterile, narrowgauge needle was used to puncture the stem to a depth of 1 to $3 \mathrm{~mm}$ through the droplets of inoculum. This resulted in the droplets of suspension being drawn into the stem xylem. Different sides of the stem were inoculated on each plant. Three separate grapevines were inoculated with each tested strain in each experiment. All results presented are from at least three independent experiments. Plants were maintained in the greenhouse for up to 3 months.

DNA primers used were synthesized by Integrated DNA Technologies (Coralville, IA, U.S.A.). Total DNA was extracted from Temecula using the Amersham (Buckinghamshire, England) GenomicPrep Cells and Tissue DNA Isolation Kit. Plasmid DNA was extracted from Temecula and from E. coli using the Qiagen (Valencia, CA, U.S.A.) plasmid mini kit.

\section{Generation of tolC mutants.}

The entire tolC open reading frame (NP_780144.1), without its native promoter, was amplified by PCR from PD strain Temecula total DNA using primers JRXF-F (5'-gaattcCTCAAA GGTGGCGAGCCAG) and JRXF-R (5'-aagcttGTATGCTTC TCCTTACTTCTCC). The resulting 1,454-bp PCR fragment was ligated to pGEM-T following the manufacturer's protocol (Promega Corporation, Madison, WI, U.S.A.), resulting in pJR6.1. The PCR-amplified insert was verified as carrying
tolC without PCR amplification errors by sequencing. A 1.1-kb $X m a I$ to BamHI fragment from pKLN18 carrying kan-2 was agarose gel purified using the Qiagen QIAquick gel extraction kit (Qiagen, Inc. Santa Clarita, CA, U.S.A.), and ligated into pBlueScript $\mathrm{SK}+$, resulting in pJR6.2. The kan-2 gene, carrying its own promoter, was used to interrupt tolC by cloning it as a BamHI fragment from pJR6.2 into pJR6.1, resulting in pJR6.3.

Cells from $10 \mathrm{ml}$ of a 4-day-old culture of Temecula grown in PD3 broth were recovered by centrifugation and then serially washed and recentrifuged using 10 , then 5 , and then $2 \mathrm{ml}$ of sterile deionized water, and resuspended in $100 \mu \mathrm{l}$ of sterile deionized water. This cell suspension $(25 \mu \mathrm{l})$ was transformed with $1 \mu \mathrm{g}$ of pJR6.3 by electroporation. Electroporated cells were allowed to recover for $24 \mathrm{~h}$ in $1 \mathrm{ml}$ of PD3 broth and were spread on PD3 plates containing kanamycin at $50 \mu \mathrm{g} / \mathrm{ml}$. These plates were incubated at $28^{\circ} \mathrm{C}$ for 7 days and single colonies were picked and then screened for interruption of tolC by PCR using appropriate primers. One mutant, M1, was verified further by Southern blot hybridization using ${ }^{32} \mathrm{P}-\mathrm{la}-$ beled PD1964 as probe (Sambrook et al. 1989).

\section{Complementation of tolC mutant M1.}

The EcoRI-SpeI tolC fragment from pJR6.1 was directionally cloned into pBBR1MCS-5, a broad-host-range cloning vector with gentamycin resistance (Kovach et al. 1995), resulting in pJR22.2, carrying tolC being driven by the lacZ promoter on the vector. The M1 (tolC::kan-2) mutant strain was transformed with pJR22.2 by electroporation as described above. Transformed colonies were selected on PD3 plates with gentamycin at $10 \mu \mathrm{g} / \mathrm{ml}$. Presence of pJR22.2 was verified by colony PCR using vector-based primers T7 and M13R.

\section{In planta survival assays}

for wild-type, tolC $^{-}$mutant M1 and complementing clone.

Plants were inoculated, as described previously, with the Temecula wild type, M1 (tolC ${ }^{-}$), and M1/pJR22.2 ( tolC $^{+}$), except that, for each inoculated strain, four plants were inoculated in the center of four internodes on each plant. Two $h$ after inoculation, the four internodes from one plant were cut using a sterile scalpel at a $5-\mathrm{cm}$ distance beyond the inoculation site on either side. These four pieces were surface sterilized by rinsing with $95 \%$ ethanol, immersed in $10 \%$ Chlorox bleach for $10 \mathrm{~min}$, and then soaked in sterile water for 10 min. Approximately $2 \mathrm{~cm}$ was cut from each end of each sterilized stem piece using a sterile scalpel (to remove any excess bleach that entered the cut tips of the stems) and each approximately $6-\mathrm{cm}$ inoculated internodal piece was ground in $1 \mathrm{ml}$ of sterile SCP buffer using a mortar and pestle. Serial dilutions of each suspension were made immediately (within $1 \mathrm{~min}$ ) and $50 \mu \mathrm{l}$ of each dilution was spotted on PD3 agar plate in triplicates. The plates were incubated at $28^{\circ} \mathrm{C}$ for 7 days, the colonies were counted, and the average of all three counts recorded as $\mathrm{CFU} / \mathrm{ml}$ for day 0 . This procedure was repeated using the remaining three inoculated plants to obtain the bacterial population counts at day 1 , day 2 , and day 3 for each strain.

A second method also was used in an attempt to recover mutant M1 from inoculated plants. Four inoculated internode pieces were cut from one plant, sterilized, and the ends cut off as above; however, instead of grinding the $6-\mathrm{cm}$ inoculated stem, the pieces were squeezed, first in the middle and then along the length toward each end of the stem, using a pair of standard pliers to express three to five large (approximately 10 $\mu 1)$ droplets of sap directly onto PD3 agar plates. Sap was collected at 60 and 90 days postinoculation in four separate experiments. 
Plasmid stability assays in the absence of selection for tolC.

The 1.1-kb XmaI and BamHI kan-2 DNA fragment from pKLN18 was blunt ended using the Klenow fragment and ligated to NcoI-digested and Klenow-blunt-ended pBBR1MCS-5. The resultant plasmid, pUFJ05 (gentamycin and kanamycin resistant) was used to transform Temecula by electroporation as described above. A single colony selected on kanamycin (50 $\mu \mathrm{g} / \mathrm{ml})$ was grown in $10 \mathrm{ml}$ of PD3 $\mathrm{Kn}(50 \mu \mathrm{g} / \mathrm{ml})$ broth at $28^{\circ} \mathrm{C}$ for 10 days. The presence of pUFJ05 was confirmed by reisolating the plasmid as described above.

Three Carignane plants were inoculated with Temecula/ pUFJ05 $\left(\mathrm{OD}_{600}=0.25\right)$ as described earlier. Plants were maintained in the greenhouse for 60 days, after which four internode stem pieces from each of three individual plants were surface sterilized and cell counts taken as described above. In addition, 20 randomly picked individual colonies from the dilution plates were analyzed for the presence of pUFJ05 by PCR using primers specific to the kanamycin resistance gene. Two colonies that were positive by PCR for the presence of pUFJ05 were grown in $10 \mathrm{ml}$ of PD3 for 10 days (to late log phase). Cells from each $10-\mathrm{ml}$ culture were recovered by centrifugation, resuspended in $200 \mu$ of alkaline lysis solution 1 (Sambrook et al. 1989), and transferred to a 1.5-ml Eppendorf tube. Plasmid DNA extraction was continued using the standard alkaline lysis protocol (Sambrook et al. 1989). Plasmid DNA was digested with restriction endonucleases EcoR1 and $B g l$ II, size fractionated by electrophoresis on $0.7 \%$ agarose gels, and visualized using ethidium bromide.

\section{Sensitivity of tolC mutants to phytochemicals, Silwet L-77, grape sap, and crude plant homogenate.}

Antimicrobial plant chemicals berberine (5,6-dihydro-9,10dimethoxybenzo-1,3-benzodioxoloquino-lizimium), genistein (4',5,7-trihydroxyisoflavone), resveratrol (3,4',5-trihydroxytrans-stilbene), and rhein (9,10-dihydro-4,5-dihydroxy-9,10dioxo-2-anthracenecarboxylic acid) were purchased from the Sigma-Aldrich Company (St. Louis). The silicone polyether surfactant Silwet L-77 was a gift of Witco Corporation (Friendly, WV, U.S.A.). Stock solutions consisted of berberine, $50 \mathrm{mg} / \mathrm{ml}$, dissolved in $100 \%$ methanol; genistein, $5 \mathrm{mg} / \mathrm{ml}$, dissolved in $80 \%$ ethanol; resveratrol, $50 \mathrm{mg} / \mathrm{ml}$, dissolved in $95 \%$ ethanol; and rhein, $10 \mathrm{mg} / \mathrm{ml}$, dissolved in $0.05 \mathrm{M}$ sodium hydroxide and filter sterilized. Autoclaved PD3 agar medium was cooled to $50^{\circ} \mathrm{C}$ and poured into sterile tubes, and aliquots of the stock solutions of each phytochemical used were mixed at various concentrations before solidifying in petri dishes. Dilution series were initially $1: 10$, followed by $1: 2$ dilutions to more accurately determine the minimum inhibitory concentrations.

Silwet L-77 was tested at 0,20 , and 200 ppm by inoculating a loopful of Temecula or M1 into $10 \mathrm{ml}$ of liquid PD3 medium in $25-\mathrm{ml}$ flasks, which were shaken at $28^{\circ} \mathrm{C}$ and $60 \mathrm{rpm}$. After 4 days of exposure, cell counts were taken using a $10 \times$ dilution series in SCP buffer as the diluent. Each dilution $(5 \mu \mathrm{l})$ was pipetted onto PD3 plates. Replicate plates were made for each treatment. Cultures of Temecula and M1 were streaked from freezer storage onto PD3 agar plates 14 days prior to use. Loopfuls of Temecula and M1 were collected from these plates and used to streak PD3 plates containing different concentrations of chemical. Each plate was divided into two halves. Temecula was streaked on one half of the plate and M1 was streaked on the other half. Plates were incubated at $30^{\circ} \mathrm{C}$. Colony growth results were recorded 14 to 21 days after streaking.

Grape sap was readily collected in the spring by cutting approximately $3 \mathrm{in}$. off the tops of well-watered, 18-in.-high grapevines in pots and collecting approximately $1.5 \mathrm{ml}$ of the free-flowing, bleeding sap with a micropipette. The sap was filter sterilized using a $0.2-\mu \mathrm{m}$ filter and kept on ice until used. Fresh sap was collected and used for each experiment. The sap $\mathrm{pH}$ ranged from 5.5 to 6.0. A loopful of each PD strain to be tested was scraped from freshly grown (7-day-old) PD3 agar plate cultures and suspended in $100 \mu \mathrm{l}$ of PD3 medium $\left(\mathrm{OD}_{600}\right.$ $=0.3)$. Each bacterial suspension $(10 \mu \mathrm{l})$ was mixed with $90 \mu \mathrm{l}$ of grape sap. After $10 \mathrm{~min}$, a 10× dilution series was made, using SCP buffer as described above. Replicate plates were made for each treatment. As controls, $10 \mu \mathrm{l}$ of each of the liquid suspensions were pipetted into individual tubes containing either $90 \mu \mathrm{l}$ of SCP buffer or PD3 medium and, after incubation for $10 \mathrm{~min}$, serial dilutions were made and plated in the same manner as above.

Crude plant homogenates $(\mathrm{CPH})$ were made from uninoculated grape internode segments as described above. Basically, $10-\mathrm{cm}$ stem segments were surface sterilized and rinsed, $2 \mathrm{~cm}$ from each end was cut off, and the remaining approximately 6$\mathrm{cm}$ stem section was ground in $1 \mathrm{ml}$ of sterile SCP buffer using a mortar and pestle. A loopful of Temecula or M1 was scraped from freshly grown (7-day-old) PD3 agar plate cultures and suspended in $100 \mu \mathrm{l}$ of PD3 medium $\left(\mathrm{OD}_{600}=0.3\right)$. Each suspension culture $(10 \mu \mathrm{l})$ was mixed with $90 \mu \mathrm{l}$ of $\mathrm{CPH}(90 \%$ $\mathrm{CPH}), 50 \% \mathrm{CPH}$ in SCP buffer $(45 \% \mathrm{CPH}), 10 \% \mathrm{CPH}$ in SCP buffer $(9 \% \mathrm{CPH})$, or SCP buffer. The mixtures were incubated for $1 \mathrm{~min}, 10 \mathrm{~min}$, or $1 \mathrm{~h}$. At each time interval, a serial dilution was made, plated, incubated, and counted as described above.

\section{ACKNOWLEDGMENTS}

This research was supported by United States Department of Agriculture grant \#2001-3442-10406 to the University of California, subaward SA6477 to the University of Florida. We thank Constance Thompson and Gary Marlow for helpful technical assistance.

\section{LITERATURE CITED}

Alfano, J., and Collmer, A. 1997. The type III (hrp) secretion pathway of plant pathogenic bacteria: Trafficking harpins, avr proteins, and death. J. Bacteriol. 179:5655-5662.

Andersen, P. C., and Brodbeck, B. V. 1989. Chemical composition of xylem exudates from bleeding spurs of Vitis rotundifolia Noble and Vitis hybrid Suwannee in relation to pruning date. Am. J. Enol. Viticult. 40:155-160.

Barabote, R. D., Johnson, O. L., Zetina, E., San Francisco, S. K., Fralick, J. A., and San Franscisco, M. J. D. 2003. Erwinia chrysanthemii tolC is involved in resistance to antimicrobial plant chemicals and is essential in phytopathogenesis. J. Bacteriol. 185:5772-5778.

Brown, M. H., Paulsen, I. T., and Skurray, R. A. 1999. The multidrug efflux protein NorM is a prototype of a new family of transporters. Mol. Microbiol. 31:394-395.

Burse, A., Weingart, H., and Ullirch, M. S. 2004. The phytoalexin-inducible multidrug efflux pump AcrAB contributes to virulence in the fire blight pathogen, Erwinia amylovora. Mol. Plant-Microbe Interact. 17:443-54.

Campbell, J. A., and Strother, S. 1996. Seasonal variation in pH, carbohydrate and nitrogen of xylem exudates of Vitis vinifera. Aust. J. Plant Physiol. 23:115-118.

Castaneda, A., Reddy, J. D., El-Yacoubi, A., and Gabriel, D. W. 2005. Mutagenesis of all eight $a v r$ genes in Xanthomonas campestris pv. campestris had no detected effect on pathogenicity, but one avr gene affects race specificity. Mol. Plant-Microbe Interact. 18:1306-1317.

da Silva, F. G., Shen, Y., Dardick, C., Burdman, S., Yadav, R. C., de Leon, A. L., and Ronald, P. C. 2004. Bacterial genes involved in type I secretion and sulfation are required to elicit the rics $\mathrm{Xa21}$-mediated innate immune response. Mol. Plant-Microbe Interact. 17:593-601.

da Silva Neto., Koide, J. F., Gomes, T., Marques, S. L., and Marilis, V. 2002. Site-directed gene disruption in Xylella fastidiosa. FEMS (Fed. Eur. Microbiol. Soc.) Microbiol. Lett. 210:105-110.

Davidson, A. L., and Chen, J. 2004. ATP-binding cassette transporters in bacteria. Annu. Rev. Biochem. 73:241-268.

Davis, M. J., Purcell, A. H., and Thomson, S. V. 1980. Isolation media for the Pierce's disease bacterium. Phytopathology 70:425-429. 
Delepelaire, P. 2004. Type I secretion in gram-negative bacteria. Biochem. Biophys. Acta 1694:149-161.

De Lima, J. E. O., Miranda, V. S., Hartung, J. S., Brlansky, R. H., Coutinho, A., and Roberto S. R. 1998. Coffee leaf scorch bacterium: Axenic culture, pathogenicity, and comparison with Xylella fastidiosa of citrus. Plant Dis. 82:94-97.

Del Sorbo, G., Schoonbeek, H.-J., and De Waard, M. A. 2000. Fungal transporters involved in efflux of natural toxic compounds and fungicides. Fungal Genet. Biol. 30:115.

Dixon, R. A. 2001. Natural products and plant disease resistance. Nature 411:843-847.

Feil, H., Feil, W. S., Detter, J. C., Purcell, A. H., and Lindow, S. E. 2003. Site-directed disruption of the fimA and fimF fimbrial genes of Xylella fastidiosa. Phytopathology 93:675-682.

Fralick, J. A. 1996. Evidence that TolC is required for functioning of the Mar/AcrAB efflux pump of Escherichia coli. J. Bacteriol. 178:58035805 .

Frey, M., Chomet, P., Glawischnig, E., Stettner, C., Grün, S., Winklmair, A., Eisenreich, W., Bacher, A., Meeley, R. B., Briggs, S. P., Simox, K., and Gierl, A. 1997. Analysis of a chemical plant defense mechanism in grasses. Science 277:696-699.

Glazebrook, J., and Ausbel, F. M. 1994. Isolation of phytoalexin-deficien mutants of Arabidopsis thaliana and characterization of their interactions with bacterial pathogens. Proc. Nat. Acad. Sci. U.S.A. 91:89558959.

Gonzales-Pasayo, R., and Martinez-Romera, E. 2000. Multiresistance genes of Rhizobium etli CFN42. Mol. Plant-Microbe Interact. 13:572577

Goodwin, P. H., DeVay, J. E., and Meredith, C. P. 1988. Roles of water stress and phytotoxins in the development of Pierce's disease of the grapevine. Physiol. Mol. Plant Pathol. 32:1-15.

Grayer, R. J., and Harborne, J. B. 1994. A survey of antifungal compounds from higher plants, 1982-1993. Phytochemistry 37:19-42.

Guilhabert, M. R., and Kirkpatrick, B. C. 2003. Transformation of Xylella fastidiosa with broad host range RSF1010 derivative plasmids. Mol. Plant Pathol. 4:279-285.

Guilhabert, M. R., Hoffman, L. M., Mills, D. A., and Kirkpatrick, B. C. 2001. Transposon mutagenesis of Xylella fastidiosa by electroporation of Tn5 synaptic complexes. Mol. Plant-Microbe Interact. 14:701-706

Guilhabert, M. R., Stewart, V. J., and Kirkpatrick, B. C. 2006. Characterization of putative rolling-circle plasmids from the gram-negative bacterium Xylella fastidiosa and their use as shuttle vectors. Plasmid 55:7080.

Hammerschmidt, R. 1999. Phytoalexins: What have we learned after 60 years? Annu. Rev. Phytopathol. 37:285-306.

Harborne, J. B. 1999. The comparative biochemistry of phytoalexin induction in plants. Biochem. Syst. Ecol. 27:335-367.

Hartung, J. S., Beretta, J., Brlansky, R. H., Soisso, J., and Lee, R. F. 1994 Citrus variegated chlorosis bacterium: Axenic culture, pathogenicity, and serological relationships with other strains of Xylella fastidiosa. Phytopathology 84:591-597.

Hatano, T., Uebayashi, H., Ito, H., Shiota, S., Tsuchiya, T., and Yoshida, T. 1999. Phenolic constituents of Cassia seeds and antibacterial effect of some naphthalenes and anthraquinones on methicillin-resistant Staphylococcus aureus. Chem. Pharm. Bull. (Tokyo) 47:1121-1127

Hopkins, D. L. 1984. Variability of virulence in grapevine among isolates of the Pierce's disease bacterium. Phytopathology 74:1395-1398.

Hopkins, D. L. 1985. Physiological and pathological characteristics of virulent and avirulent strains of the bacterium that causes Pierce's Disease of grapevine. Phytopathology 75:713-717.

Hopkins, D. L. 1989. Xylem-limited bacterial pathogens of plants, Annu. Rev. Phytopathol. 27:271-290.

Hwang, J., Zhong, X., and Tai, P. C. 1997. Interactions of dedicated export membrane proteins of the colicin $\mathrm{V}$ secretion system: CvaA, a member of the membrane fusion protein family, interacts with $\mathrm{CvaB}$ and TolC. J. Bacteriol. 179:6264-6270.

Jeandet, P., Douillet-Breuil, A-C., Bessis, R., Debord, S., Sbaghi, M., and Adrian, M. 2002. Phytoalexins from the Vitaceae: Biosynthesis, phytoalexin gene expression in transgenic plants, antifungal activity, and metabolism. J. Agric. Food Chem. 50:2731-2741.

Koronakis, V., Eswaran, J., and Hughes, C. 2004. Structure and function of TolC: The bacterial exit duct for proteins and drugs. Annu. Rev. Biochem. 73:467-489.

Kovach, M. E., Elzer, P. H., Hill, D. S., Robertson, G. T., Farris, M. A., Roop, R. M., II, and Peterson, K. M. 1995. Four new derivatives of the broad-host-range cloning vector pBBR1MCS, carrying different antibiotic-resistance cassettes. Gene 166:175-176.

Krummenacher, P., and Narberhaus, F. 2000. Two genes encoding a putative multidrug efflux pump RND/MFP family are cotranscribed with an rpoH gene in Bradyrhizobium japonicum. Gene 241:247-254.
Lally, E. T., Hill, R. B., Kieba, L. R., and Korstoff., J. 1999. The interaction between RTX toxins and target cells. Trends Microbiol. 7:356-361.

Li, X.-Z., and Nikaido, H. 2004. Efflux-mediated drug resistance in bacteria. Drugs 64:159-204.

Lomovskaya, O., and Lewis, K. 1992. emr, an Escherichia coli locus for multidrug resistance. Proc. Natl. Acad. Sci. U.S.A. 89:8938-8942.

Ma, D., Cook, D. N., Alberti, M., Pon, N. G., Nikaido, H., and Hearst, J. E. 1993. Molecular cloning and characterization of acrA and acrE genes of Escherichia coli. J. Bacteriol. 175:6299-6313.

McNally, D. J., Wurms, K. V., Labbe, C., and Belangera, R. R. 2003. Synthesis of C-glycosyl flavonoid phytoalexins as a site-specific response to fungal penetration in cucumber. Physiol. Mol. Plant Pathol. 63:293303.

Minsavage, G. V., Thompson, C. M., Hopkins, D. L., Leite, R. M. V. B., and Stall, R. E. 1994. Development of a polymerase chain reaction protocol for detection of Xylella fastidiosa in plant tissue. Phytopathology 84:446-461.

Newman, K. L., Almeida, R. P., Purcell, A. H., and Lindow, S. E. 2003. Use of a green fluorescent strain for analysis of Xylella fastidiosa colonization of Vitis vinifera. Appl. Environ. Microbiol. 69:7319-7327.

Nikaido, H. 1996. Multidrug efflux pumps of Gram-negative bacteria. J. Bacteriol. 178:5853-5859.

Oresnik, I. J., Twelker, S., and Hynes, M. F. 1999. Cloning and characterization of a Rhizobium leguminosarum gene encoding a bacteriocin with similarities to RTX toxins. Appl. Environ. Microbiol. 65:2833-2840.

Osbourn, A. E. 1996. Preformed antimicrobial compounds and plant defense against fungal attack. Plant Cell 8:1821-1831.

Palumbo, J. D., Kado, C. I., and Phillips, D. A. 1998. An isoflavonoid-inducible efflux pump in Agrobacterium tumefaciens is involved in competitive colonization of roots. J. Bacteriol. 180:3107-3113.

Pao, S. S., Paulsen, I. T., and Saier, M. H., Jr. 1998. Major facilitator superfamily. Microbiol. Mol. Biol. Rev. 62:1-34

Papadopoulou, K., Melton, R. E., Leggett, M., Daniels, M. J., and Osbourn A. E. 1999. Compromised disease resistance in saponin-deficient plants. Plant Biol. 96:12923-12928.

Paulsen, I. T., Park, J. H., Choi, P. S., and Saier, M. H. 1997. A family of Gram-negative bacterial outer membrane factors that function in export of proteins, carbohydrates, drugs and heavy metals from gram-negative bacteria. FEMS (Fed. Eur. Microbiol. Soc.) Microbiol. Lett. 156:1-8.

Paulsen, I. T. 2003. Multidrug efflux pumps and resistance: Regulation and evolution. Curr. Opin. Microbiol. 6:446-451.

Peng, W. T., and Nester, E. W. 2001. Characterization of a putative RNDtype efflux system in Agrobacterium tumifaciens. Gene 270:245-252.

Pierce, M. L., Cover, E. C., Richardson, P. E., Scholes, V. E., and Essenberg, M. 1996. Adequacy of cellular phytoalexin concentrations in hypersensitively responding cotton leaves. Physiol. Mol. Plant Pathol. 48:305324.

Purcell, A. H. 1997. Xylella fastidiosa, a regional problem or global threat? J. Plant Pathol. 79:99-105.

Qin, X., and Hartung, J. S. 2001. Construction of a shuttle vector and transformation of Xylella fastidiosa with plasmid DNA. Curr. Microbiol. 43:158-162

Saier, M. H., Jr., Eng, B. H., Fard, S., Garg, J., Haggerty, D. A., Hutchinson, W. J., Jack, D. L., Lai, E. C., Liu, H. J., Nusinew, D. P., Omar, A. M. Pao, S. S., Paulsen, I. T., Quan, J. A., Sliwinski, M., Tseng, T. T., Wachi, S., and Yound, G. B. 1999. Phylogenetic characterization of novel transport protein families revealed by genome analyses. Biochim. Biophys. Acta 1422:1-56.

Sambrook, J., Fritsch, E. F., and Maniatis, T. 1989. Molecular Cloning: A Laboratory Manual. Cold Spring Harbor Laboratory Press, Cold Spring Harbor, NY, U.S.A

Schmeller, T., Latz-Bruning, B., and Wink, M. 1997. Biochemical activities of berberine, palmatine and sanguinarine mediating chemical defence against microorganisms and herbivores. Phytochemistry 44:257266.

Schoonbeek, H., Del Sorbo, G., and De Waard, M. A. 2001. The ABC transporter BcatrB affects the sensitivity of Botrytis cinerea to the phytoalexin resveratrol and the fungicide fenpiclonil. Mol. Plant-Microbe Interact. 14:562-571

Sharff, A., Fanutti, C., Shi., J., Calladine, C., and Luisi, B., 2001. The role of the TolC family in protein transport and multidrug efflux: From stereochemical certainty to mechanistic hypothesis. Eur. J. Biochem. 268:5011-5026.

Sheldon, A. T. 2005. Antibiotic resistance: A survival strategy. Clin. Lab. Sci. 18:170-80.

Simpson, A. J. G., Reinach, F. C., Arruda, P., Abreu, F. A., Acencio, M., Alvarenga, R., Alves, L. M. C., Araya, J. E., Baia, G. S., Baptista, C. S., Barros, M. H., Bonaccorsi, E. D., Bordin, S., Bove, J. M., Briones, M. R. S., Bueno, M. R. P., Camargo, A. A., Camargo, L. E. A., Carraro, D. M., Carrer, H., Colauto, N. B., Colombo, C., Costa, F. F., Costa, M. C. 
R., Costa-Neto, C. M., et al. 2000. The genome sequence of the plant pathogen Xylella fastidiosa. Nature 406:151-157.

Tegos, G., Stermitz, F. R., Lomovskaya, O., and Lewis, K. 2002. Multidrug pump inhibitors uncover remarkable activity of plant antimicrobials. Antimicrob. Agents Chemother. 46:3133-3141.

Tseng, T. T., Gratwick, K. S., Kollman, J., Park, D., Nies, D. H., Goffeau, A., and Saier, M. H., Jr. 1999. The RND permease superfamily: An ancient, ubiquitous and diverse family that includes human disease and development proteins. J. Mol. Microbiol. Biotechnol. 1:107-125.

Vanamala, A., and Gabriel, D. W. 2006. Stable transformation of Xylella fastidiosa with small repW shuttle vector pUFR047. Curr. Sci. 91:344-347.

VanEtten, H. Temporine, E., and Wasmann, C. 2001. Phytoalexin (and phytoanticipin) tolerance as a virulence trait: Why is it not required by all pathogens? Physiol. Mol. Plant Pathol. 59:83-93.

Van Sluys, M. A., de Oliveira, M. C., Monteiro-Vitorello, C. B., Miyaki, C. Y., Furlan, L. R., Camargo, L. E. A., da Silva, A. C. R., Moon, D. H., Takita, M. A., Lemos, E. G. M., Machado, M. A., Ferro, M. I. T., da Silva, F. R., Goldman, M. H. S., Goldman, G. H., Lemos, M. V. F., ElDorry, H., Tsai, S. M., Carrer, H., Carraro, D. M., de Oliveira, R. C.,
Nunes, L. R., Siqueira, W. J., Coutinho, L. L., Kimura, E. T., et al. 2003. Comparative analyses of the complete genome sequences of Pierce's disease and citrus variegated chlorosis strains of Xylella fastidiosa. J. Bacteriol. 185:1018-1026.

Wandersman, C., and Delepelaire, P. 1990. TolC, an Escherichia coli outer membrane protein required for hemolysin secretion. Proc. Natl. Acad. Sci. U.S.A. 87:4776-4780.

Wells, J. M., Raju, B. C., Hung, H., Weisburg, W. G., Mandelco-Paul, L., and Brenner, D. J. 1987. Xylella fastidiosa gen. nov., sp. nov.: Gramnegative, xylem limited, fastidious plant related to Xanthomonas spp. Int. J. Syst. Bacteriol. 37:136-143.

Yu, O., Woosuk, J., Shi, J., Croes, R. A., Fader, G. M., McGonigle, B., and Odel, J. T. 2000. Production of the isoflavones genistein and daidzein in non-legume and monocot tissues. Plant Physiol. 124:781-793.

Zapata, C., Deleens, E., Chaillou, S., and Magne, C. 2004. Partitioning and mobilization of starch and $\mathrm{N}$ reserves in grapevine (Vitis vinifera L.). J. Plant Physiol. 161:1031-1040.

Zgurskaya, H. I., and Nikaido, H. 2000. Multidrug resistance mechanisms: Drug efflux across two membranes. Mol. Microbiol. 37:219-225. 